\title{
Pola Adaptasi Penghuni Gua Budaya Toala
}

\section{Indah Asikin Nurani}

Keywords: cave, settlement, prehistory, holocene, culture

\section{How to Cite:}

Nurani, I. A. (1993). Pola Adaptasi Penghuni Gua Budaya Toala. Berkala Arkeologi, 13(2), 1-17. https://doi.org/10.30883/jba.v13i2.573

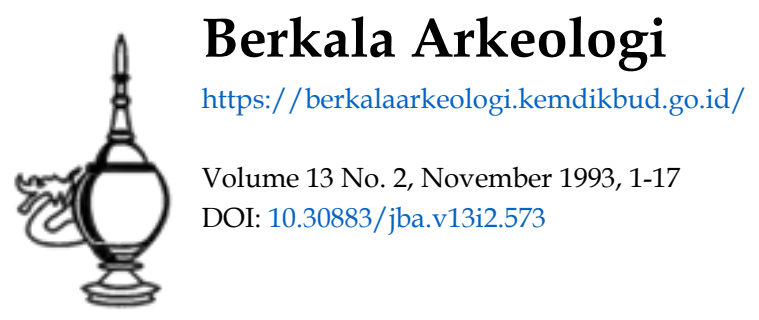




\author{
Indah Asikin Nurani \\ (Balai Arkeologi Yogyakarta)
}

Kehidupan penghuni gua Budaya Toala berlangsung sejak Kala Pasca Plestosen hingga awal masehi. Kehidupan Budaya Toala ini berlangsung cukup lama dan mampu bertahan beratus-ratus tahun lamanya. Kehidupan budaya tersebut masih sangat bergantung pada potensi ekologi sumber alam sekitarnya. Hal ini menarik perhatian untuk diungkap lebih dalam, terutama mengenai pola adaptasi yang diterapkan oleh penghuni gua sehingga budaya ini mampu bertahan cukup lama.

Dalam membahas pola adaptasi yang terjadi pada pola pemukiman gua Budaya Toala, terlebih dahulu akan dibahas tentang kondisi lingkungan alam sekitarnya dan aktivitas manusia pendukungnya. Di dalam mengatur kehidupan dirinya, manusia saat itu melakukan segala aktivitasnya ditujukan untuk kegiatan perekonomian. Selain itu manusia juga melakukan kegiatan yang berkenaan dengan cara bagaimana mereka menyiasati dan memperlancar nilai dan sikap dalam masyarakat, hal ini merupakan suatu aktivitas yang disebut sosial - politik (Trigger, 1973: 313).

Segala aktivitas manusia baik yang menyangkut perekonomian maupun kepentingan sosial - politik, jika pada suatu saat hilang, maka yang akan tertinggal hanya pola pemukimannya serta alat-alat yang pernah dipergunakan oleh penghuninya. Jadi dapatlah dimengerti bahwa suatu pola pemukiman merupakan ungkapan suatu aspek sosial dari suatu kebudayaan (Ibid).

Pola pemukiman Budaya Toala merupakan pemukiman secara berpindah-pindah (Indah, 1992). Pola pemukiman tersebut dianggap sesuai dengan keadaan lingkungan alam sekitarnya dan penyesuaian atau adaptasi yang dilakukannya. Berdasarkan kenyataan tersebut, maka akan ditinjau penyebabnya dengan mengamati pola musim yang berlaku di daerah ini sebagai sarana penyesuaian terhadap sumber makannya yang dipengaruhi oleh potensi ekologi dan daur waktu. Selain pola musim, tidak tertutup kemungkinan adanya faktor lain 
seperti ledakan penduduk. Hal tersebut didasarkan atas ditemukannya sejumlah besar gua-gua hunian dan memiliki kandungan temuan yang beraneka ragam dengan kurun waktu hunian yang berbeda-beda. Ledakan penduduk dalam Budaya Toala ini terjadi pada kurun waktu tertentu, yang akan dijelaskan pada Bab III.

Pola musiman sebagai sarana dalam pemukiman berpindahpindah disebabkan adanya daya lenting yang rendah. Daya lenting adalah kemampuan sistem lingkungan dalam menerima gangguan, dan belajar dari gangguan yang ada. Pemahaman dari adanya gangguan berarti mengubah gangguan itu menjadi suatu informasi. Informasi kemudian digunakan untuk menyesuaikan kelakuan terhadap kondisi baru. Dengan demikian konsep daya lenting mengandung arti adaptatif. Sifatnya yang adaptatif tersebut menjadikan sistem lingkungan dapat pula mempertahankan kelangsungan hidup manusia sekitarnya (Sumarwoto, 1987: 80).

Dalam pola musiman sebagai sarana adaptasi terhadap sistem lingkungan alam sekitar, akan dipertimbangkan pula saat-saat tersedianya binatang buruan dan tumbuh-tumbuhan (buah-buahan dan sayuran). Dengan pertimbangan tersebut kehidupan manusia lebih terjamin karena adanya penjadualan waktu. Binatang buruan manusia Budaya Toala merupakan binatang mamalia yang lebih banyak merupakan jenis herbivora atau binatang pemakan tumbuh-tumbuhan seperti Anoa, Kuskus, Babirusa dan sebagainya (periksa Daftar No. 1). Sehubungan dengan hal tersebut, akan dibahas tentang perilaku dan keberadaan fauna tersebut sebagai sumber kehidupan manusia. Dengan dikenalnya strategi adaptasi tersebut muncul permasalahan lain yaitu ledakan jumlah penduduk, yang dapat dibuktikan dengan penghunian beberapa gua yang semula tidak dihuni menjadi dihuni (periksa Daftar No. 3). Populasi atau jumlah penduduk merupakan suatu gejala biologis yang biasanya bergantung pada faktor-faktor sosial dan lingkungan. Populasi atau kependudukan sebagai salah satu bagian dari ekosistem berhubungan erat dengan potensi sumbersumber alam serta kelangsungan hidup atau teknologi yang ada dalam suatu kelompok masyarakat. Jika terjadi perubahan lingkungan, maka jumlah penduduk dan faktor-faktor sosialnya akan berubah pula (Ernestene, 1973: 339).

Perubahan lingkungan yang terjadi tidak dapat lepas dari kehidupan manusia, untuk beradaptasi dalam mempertahankan hidupnya. Dikenal, dibuat, dan dikembangkannya alat-alat berburu dan 
mengumpulkan makanan sebagai salah satu bukti adaptasi manusia saat itu terhadap lingkungannya. Meskipun demikian ketergantungan mereka terhadap lingkungannya tetap berlangsung terus (Ibid: 340 ). Kelangsungan hidup manusia yang masih bergantung pada lingkungannya tersebut akan mengakibatkan peranan geografis, flora dan fauna menjadi sangat besar dalam menunjang perubahan jumlah penduduk.

Berangkat dari konsep dan perilaku manusia masa itu yang masih sangat menggantungkan kehidupannya pada potensi ekologi dan sumber alam lingkungan sekitarnya, maka akan dibahas tentang pola adaptasi penghuni gua pendukung Budaya Toala. Permasalahan yang mendasari penulisan ini adalah sebagai berikut:

1. Berapa lama berlangsungnya pemukiman penghuni gua pendukung Budaya Toala ini dan bagaimana pola pemukimannya?

2. Bagaimana strategi adaptasi yang diterapkan sehingga penghuni gua pendukung Budaya Toala ini bertahan lama?.

Tulisan ini diharapkan dapat menjawab dan menjelaskan lamanya kurun waktu penghuni gua pendukung Budaya Toala dengan strategi adaptasi yang dilakukan.

Daerah Sulawesi Selatan mempunyai dua jadual musim yang berbeda, yang mempengaruhi pola kehidupan ekonomi penduduk. Pada Bulan November sampai dengan Maret terjadi musim hujan di bagian barat propinsi. Selanjutnya pada Bulan Mei sampai Oktober, giliran bagian timur propinsi yang mengalami musim hujan. Keadaan ini merupakan penyebab kegiatan perekonomian (mengolah tanah) berlangsung sepanjang tahun secara bergilir (Anthony, 1987: 49).

Situs gua-gua pendukung Budaya Toala yang selama ini diteliti oleh beberapa ahli seperti Sarasin, Seojono, van Heekeren, lan Glover, Hooijer dan sebagainya tersebar hampir di seluruh Propinsi Sulawesi Selatan yang meliputi Kabupaten Bone, Maros, Bantaeng, dan Bulukumba. Masing-masing Kabupaten tersebut memiliki kompleks gua yang merupakan satu komunitas penghuni gua tingkat meso (structure meso settlement). Ditinjau dari kondisi geografis, keletakan beberapa kompleks gua tersebut berada pada daerah pegunungan, 
lembah, dan pantai. Secara khusus keseluruhan gua tersebut pernah diteliti oleh van Heekeren. Dalam penelitian di Gua Panganreang Tudea, van Heekeren menyimpulkan adanya 3 lapisan Budaya Toala yaitu Toala Atas (I), Toala Tengah (II), dan Toala Bawah (III) (Soejono, 1984: 142-143).

Daerah Sulawesi Selatan sebagian besar merupakan daerah batu kapur yang dalam istilah geomorfologis disebut daerah bentang lahan karst yang terjadi karena daya larut batuan dasar yang sangat tinggi. Bentang lahan karst di daerah ini dapat dibedakan dalam dua bentuk utama yang khas untuk daerah tropik basah. Karst dengan bukit-bukit ditemukan di sebelah utara Bone dan karst menara terdapat di bukit-bukit di sekitar Maros meliputi kira-kira $400 \mathrm{~km}^{2}$ (Anthony, 1987: 31).

Bukit-bukit Maros umumnya mempunyai ketinggian antara 150 sampai $\mathbf{3 0 0}$ meter dari permukaan air laut (dpa) tetapi ada yang mempunyai ketinggian mencapai 564 meter dpa. Ketinggian dasar lembah semakin ke arah timur semakin tinggi hingga mencapai ketinggian $120 \mathrm{~m}$ dpa. Morfologi perbukitan disebabkan oleh sungai di bagian timur yang mengalir ke barat melalui gua-gua yang makin lebar dan dalam. Terjalnya tebing- tebing lembah sampai pada posisi tegak lurus disebabkan oleh longsoran bagian bawah. Longsoran bagian bawah ini terjadi karena pengikisan sungai yang terletak di sekeliling kaki bukit dan tidak melintasi dataran aluvial. Pelongsoran di bagian bawah kaki bukit tersebut membentuk tempat-tempat perlindungan atau semacam ceruk dengan tinggi 2 sampai 3 meter dan kedalaman 1 atau 2 meter, bahkan di antaranya ada yang meluas sampai ke dalam bukit (Anthony, $1987: 520$ ).

Kabupaten Bantaeng merupakan daerah dengan lahan yang sangat bervariasi bentuknya, bahkan dijuluki daerah tiga dimensi (SPSP Sul-Sel, 1986). Hal ini disebabkan karena pada bagian selatan merupakan daerah pantai yang sangat landai, dibagian tengah terdapat dataran rendah yang sangat tepat digunakan untuk lahan pertanian, dan di bagian paling utara merupakan dataran tinggi. Keadaan topografi tersebut ketinggiannya bervariasi antara $400-2300$ meter dpa., dan daerah ini merupakan kawasan kaki Gunung Lampobatang.

Situs Gua Ara di Kabupaten Bulukumba menunjukkan susunan geologis yang terdiri dari gugusan batu kapur yang terangkat pada Jaman Quarter, dan sebagian lagi ditutup oleh hasil letusan Gunung Lampobatang dekat Kajang. Beberapa teras pantai tampak jelas, dan 
berdasarkan penelitian para ahli geologi dapat ditunjukkan adanya 7 teras pada pantai Bulukumba. Letak Situs Gua Ara pada masa prasejarah terletak pada teras pantai ke-3 yang berada pada ketinggian $30 \mathrm{~cm}$ dpa. (Heekeren, 1972: 110).

Kondisi geografis dan geologis yang terjadi di daerah Sulawesi Selatan ini mengakibatkan adanya pola tersendiri bagi manusia dalam mempertahankan kehidupannya. Sebagaimana telah diketahui bahwa pola pemukiman pendukung Budaya Toala adalah pola bermukim secara berpindah-pindah. Hal tersebut lebih tepat diterapkan dan sesuai dengan kondisi alam dan tuntutan hidupnya. Berdasarkan data arkeologis, kondisi geologis dan geografis, memungkinkan pilihan bermukim secara berpindah-pindah sangat tepat diterapkan penghuni gua pendukung Budaya Toala ini.

Kondisi geografis situs-situs gua Budaya Toala (lihat Peta) dan tingkat lapisan budaya yang telah diklasifikasikan oleh van Heekeren, dapat ditarik suatu asumsi adanya pola sebaran penghunian yang dilakukan oleh penghuni gua. Data arkeologis yang ditemukan pada masing-masing gua cenderung mengarah dari daerah pegunungan $\mathrm{ke}$ daerah pantai (Indah, 1992). Secara administratif kompleks gua yang berada di Kabupaten Bone dan sebagian Maros yang berada di daerah pegunungan masa huniannya berada pada masa Toala Bawah dan Tengah. Kompleks gua yang berada di sebagian Kabupaten Maros yang terletak di daerah lembah dan kompleks gua di Kabupaten Bantaeng, serta Bulukumba yang terletak di daerah pantai lebih cenderung dihuni pada masa Toala Tengah sampai Toala Atas. Dalam penghunian gua tidak tertutup kemungkinan penempatan gua yang pernah dihuni dan ditinggalkan, dan kemudian dihuni kembali pada masa jauh sesudahnya, atau hanya ditinggalkan untuk beberapa musim saja.

Berdasarkan kondisi geografis dan geomorfologi, bentang lahan karst di Sulawesi Selatan yang cenderung bervariasi dengan pola musim yang bergilir, mempertegas asumsi adanya penjadualan musim dalam pola perolehan sumber makanan yang didasarkan pada potensi ekologi alam sekitarnya. Telah dijelaskan sebelumnya, bahwa suatu pola pemukiman komposisinya senantiasa dalam keadaan tidak tetap. Perubahan itu bukan saja terjadi dari musim ke musim tetapi dari hari ke hari bahkan dari jam ke jam. Binatang siang diganti binatang malam pada waktu senja, dan pergantiannya berbalik lagi pada waktu fajar. Bunga berkembang pada musim tertentu dan layu pada musim 
berikutnya yang selanjutnya berganti menjadi buah yang berbuah ranum dan lebat pada musim tertentu dan lenyap pada musim berikutnya.

Tidak selamanya alam menyediakan tanah yang subur, buahbuahan yang selalu ranum atau binatang buruan yang berjumlah banyak. Pada suatu waktu semua itu akan berkurang dan tanah makin habis tingkat kesuburannya. Akibatnya tanah yang kurang subur ditinggalkan kemudian tanah baru dibuka di tempat lain dengan jalan menebangi hutan-hutan dan membakar semak-semak belukar yang telah mengering. Proses seperti ini berlaku berulang-ulang di banyak tempat dalam waktu yang lama (Soejono, 1984: 200; Bargamini, 1981: 184-185).

Kenyataan tersebut mendasari pola pemukiman yang diterapkan pada Budaya Toala dengan strategi adaptasi yang digunakan yaitu pola musiman. Hal ini didukung pula dengan adanya iklim hujan musiman yang terdapat di Sulawesi Selatan sehingga hutan yang ada pun akan terpengaruh oleh tersedianya air yang sifatnya musiman tersebut. Dengan keadaan seperti ini, tidak mengherankan apabila penghuni gua di berbagai wilayah Sulawesi Selatan menyiasati potensi ekologinya dengan penjadualan sesuai musim yang menyediakan sumber kehidupannya. Hal ini disebabkan perbedaan kedua musim tersebut sangat menyolok, sebagai contoh sungai di daerah pegunungan akan kering pada musim kemarau dan mengalir kembali pada musim penghujan. Selain itu pada musim kemarau di daerah pegunungan sering terjadi kebakaran hutan karena sangat kering dan panas (Anthony, 1987).

Penjadualan sebagai adaptasi terhadap lingkungan alam sekitarnya, dilakukan dengan maksud agar senantiasa tersedia sumber makanan yang dibutuhkan. Hal ini terjadi seperti pada musim hujan mereka akan menghuni gua-gua yang berada di pegununganpegunungan (dataran tinggi), dan pada saat musim kemarau mereka turun ke daerah dekat pantai, demikian seterusnya. Cara bermukim seperti ini menimbulkan kegiatan yang berbeda-beda menurut musimnya dalam mencari makan. Daur masa matang, berlimpah atau berkurangnya makanan yang tersedia diselaraskan dengan kegiatan yang dilakukan sesuai dengan musim. Dengan kata lain manusia saat itu dituntut mengetahui kondisi alam sekitarnya dengan potensi ekologi yang tersedia.

Kondisi fauna sebagai binatang buruan pendukung Budaya Toala 
telah disebutkan pada Bab I yaitu Anoa, Babirusa, Kuskus, dan sebagainya. Berikut ini akan dijelaskan tentang perilaku dan kehidupan jenis fauna tersebut sebagai gambaran kondisi ekologi daerah Sulawesi Selatan. Kondisi riil ekologi Sulawesi Selatan ini akan dijelaskan didasarkan penelitian Anthony sebagaimana yang tertuang dalam bukunya Ekologi Sulawesi.

Anoa jenis $d$. depressicornis dan Anoa $d$. Quarlesi biasanya hidup di dataran rendah dan di gunung-gunung. Selain itu Anoa gunung pun kadang-kadang ditemukan pada daerah berketinggian sama dengan permukaan laut, sedangkan Anoa dataran rendah kadangkadang ditemukan di gunung-gunung yang tinggi. Hal ini kemungkinan disebabkan oleh adanya musim tertentu, sehingga mereka berpetualang ke daerah lain untuk mencari makan. Sedangkan Kuskus Beruang atau Phalanger Ursinus merupakan binatang yang besar. Kuskus yang paling kecil dari semua jenisnya yaitu Phalanger Celebensis merupakan binatang malam dan oleh sebab itu jarang terlihat.

Kuskus Beruang atau Phalanger Ursinus adalah binatang yang besar berwarna pirang, pemakan daun dan biasanya ditemukan berpasangan yang aktif mencari makan pada siang hari. Kuskus kerdil atau Phalanger Celebensis merupakan binatang yang aktif pada malam hari dan pemakan buah, serta ditemukan berpasangan sebagai penghuni pohon.

Babirusa merupakan binatang malam meskipun kadang juga terlihat pada waktu siang. Babirusa lebih banyak memakan buah dan memecah kayu yang lunak untuk mendapatkan larva-larva Kumbang. Buah yang menjadi makanan utamanya adalah pucung (pangi) Pangium edule (flac) yang potensial mengandung racun. Buah yang merupakan makanan utama di daerah pantai adalah kelapa, tetapi Babirusa bukan merupakan binatang pengganggu (hama) kelapa, justru Sus Celebensis merupakan binatang hama kelapa.

Musang atau Macrogalidia Musschenbroekii hidup di hutan pegunungan. Binatang ini jarang sekali tampak, namun binatang ini hidup di daerah pegunungan yang ditunjukkan dengan adanya jejakjejak. Jejak tersebut seperti tinja dan garukan pada pohon yang berketinggian 2,5 meter di atas tanah. Adapun makanan Musang ini meliputi sebagian besar binatang menyusui kecil seperti Tikus, dan kadang Kuskus atau Phalanger Celebensis, anak babi, serta Ayam. 
Pola pemukiman Budaya Toala menurut hasil penelitian dan analisis radicarbon yang dilakukan oleh lan Glover berlangsung sejak $32160 \pm 250$ BP sampai dengan 400 SM (lihat Daftar No: 5)(Glover, 1984: 37-44). Penelitian lan Glover tersebut didasarkan pada data yang ditemukan di berbagai gua pendukung Budaya Toala. Pertanggalan Toala III ditentukan pada temuan serpih bilah dan lancipan Levallois yang berasosiasi dengan arang dan kerang air tawar di Situs Leang Burung 2. Pertanggalan Toala III diperkirakan berumur antara $32160 \pm$ 330 BP sampai dengan $20150 \pm 250$ BP. Adapun pertanggalan Toala II didasarkan pada temuan arang dan kerang air tawar yang berasosiasi dengan serpih bilah kecil, mikrolit, serta tulang Babi yang ditemukan di Situs Ulu Leang. Perkiraan umur Toala II ini adalah berumur antara $10740 \pm 50$ BP sampai $5740 \pm 230$ BP. Selanjutnya pertanggalan Toala I didasarkan pada umur Toala I yang menunjukkan kekhususan yang berkembang paling muda dalam industri serpih bilah yaitu tembikar. Unsur tembikar tertua yang ditemukan di situs-situs Budaya Toala merupakan tembikar polos dan berhias. Tembikar polos ditemukan di Situs Ulu Leang dan ditemukan berasosiasi dengan budidaya padi jenis Oryza Sattiva. Perkiraan umur tembikar polos ini menunjukkan pertanggalan 4000 SM. Sedangkan tembikar berhias yang ditemukan di Ulu Leang, Ulu Wae, Leang Burung 1 di Kabupaten Maros, dan Gua Batu Ejaya di Kabupaten Bantaeng merupakan tembikar berhias unsur tradisi Kalanay. Berdasarkan temuan tersebut diperkirakan lapisan Toala I ini bertahan sampai dengan 700 - 400 SM.

Berdasarkan analisis radiocarbon yang dilakukan oleh Glover tersebut, van Stein Callenfels membuktikan pula adanya temuan yang lebih muda dari pertanggalan tersebut di atas. Hal tersebut didasarkan pada temuan gelang perunggu di Gua Batu Ejaya, yang diperkirakan dihuni sampai dengan 300 SM (Soejono, 1984: 142).

Dengan kenyataan tersebut, maka tampak jelas bahwa pola adaptasi yang diterapkan oleh manusia pendukung Budaya Toala telah mapan, yaitu pola musiman dengan penjadualan. Di lain pihak dengan kemapanan strategi adaptasi tersebut muncul permasalahan lain yaitu ledakan jumlah penduduk.

Sebagaimana telah diuraikan di atas bahwa situs-situs gua pendukung Budaya Toala tersebar hampir di seluruh Propinsi Sulawesi Selatan. Sementara itu kondisi geografis propinsi ini pun bervariasi 
yang meliputi daerah pegunungan, lembah dan daerah sekitar pantai. Kondisi geografis dengan pola musiman yang diterapkan dalam pola pemukimannya tersebut menyebabkan berbagai kegiatan disesuaikan kondisi potensi ekologi dan lingkungan alam sekitarnya sebagaimana telah dijelaskan pada Bab II.

Pada Bab II dijelaskan bahwa van Heekeren telah mengklasifikasikan lapisan Budaya Toala dalam 3 lapisan. Dari klasifikasi lapisan budaya tersebut dan didukung dengan hasil analisis radio carbon yang dilakukan oleh lan Glover, maka akan diketahui kurun waktu hunian pada masing-masing gua. Hal tersebut untuk mengetahui pada kurun waktu mana ledakan jumlah penduduk terjadi pada pola pemukiman Budaya Toala ini.

Klasifikasi masa hunian pada masing-masing gua tersebut didasari atas jenis temuan yang terkandung pada masing-masing gua sebagai unsur lapisan budaya yang bersangkutan yaitu Toala III sampai dengan Toala I (lihat Daftar No. 3). Pada lapisan Budaya Toala III gua-gua huniannya meliputi: Leang Burung 2 (sebagaimana yang menjadi dasar pertanggalan Glover), Leang Karassa, Leang Panisi Ta'butu, dan Gua Panganreang Tudea. Toala II situs-situs gua yang dihuni meliputi: Leang Saripa, Leang PattaE, Ulu Leang, Leang Cakondo, Leang Ululeba, Leang Balisao, Leang Tomatua Kacicang, Gua Bola Batu, Gua Cadang, Gua Panganreang Tudea, dan Gua Batu Ejaya. Sedangkan Toala I gua yang dihuni meliputi: Leang Saripa, Leang PattaE, Ulu Leang, Gua Panganreang Tudea, dan Gua Batu Ejaya, dan Gua Ara.

Berdasarkan tinjauan kurun waktu hunian pada masing- masing gua tersebut, maka dapat diketahui bahwa ledakan penduduk terjadi pada kurun waktu Toala II atau perkiraan pertanggalan antara $10740 \pm$ 50 BP sampai $5740 \pm 230$ BP (periksa Daftar no. 4). Hal tersebut tampak jelas dengan penghunian gua-gua yang semula tidak dihuni menjadi dihuni. Pada daftar no. 4 tampak jelas bahwa pada kurun waktu Toala III gua-gua yang dihuni sekitar 4 gua dan pada kurun waktu Toala II gua yang dihuni melonjak sekitar 11 gua atau tiga kali lipat. Dengan melihat keletakan geografis gua-gua tersebut sebagian besar berada di daerah pegunungan, hal ini disebabkan pegunungan lebih banyak menyediakan kebutuhan binatang buruan. Sehingga tanpa ragu lagi aktivitas penghuni gua tersebut sebagian besar berburu dan mengumpulkan makanan. Hal tersebut didasarkan pada temuan artefak dan ekofak pada masing-masing gua (lihat Daftar No. 2 dan 
periksa Daftar no. 1).

Aktivitas berburu dan mengumpulkan makanan sangat dipengaruhi oleh kondisi lingkungan alam sekitarnya, yaitu musim dan potensi ekologi. Berdasarkan pada pembahasan Bab II telah dapat diketahui bagaimana perilaku dan pola hidup masing- masing binatang buruan yang dipengaruhi ruang dan waktu. Tidak selamanya binatang buruan tersebut ada dan tersedia dalam jumlah yang banyak. Strategi adaptasi yang diterapkan pendukung Budaya Toala tersebut tentunya dilandasi pada pengetahuan alam dan perilaku binatang buruan. Sehingga tanpa diragukan lagi pola adaptasi yang dilakukan sebagai kearifan masyarakat waktu itu adalah dengan penjadualan yang disesuaikan dengan pola musim yang berlaku.

\section{IV}

Berdasarkan penjelasan dan uraian di atas, maka dapat disimpulkan sebagai berikut:

1. Pola permukiman pendukung Budaya Toala merupakan permukiman secara berpindah-pindah. Perpindahan antar situs tersebut berlangsung dalam satu komunitas dan antar komunitas.

2. Pola permukiman yang masih berpindah-pindah tersebut dikarenakan tuntutan alam dan potensi ekologi sekitarnya. Adapun pola adaptasi yang diterapkan adalah pola musiman dan tuntutan ledakan jumlah penduduk.

3. Pola musiman yang diterapkan sebagai pola adaptasi yang digunakan pendukung Budaya Toala tersebut melibatkan aktivitas yang dilakukan disesuaikan dengan musim yang berlangsung.

4. Penyesuaian aktivitas dengan musim yang berlangsung didukung dengan penjadualan dan kondisi geografis dan geologis yang ada di Sulawesi Selatan. Hal tersebut mengakibatkan aktivitas dan perpindahan penduduk berlangsung secara bergilir atau adanya penjadualan. Musim kemarau dan musim penghujan akan diikuti dengan aktivitas dan penghunian pada daerah tertentu. 
5. Pola musiman secara penjadualan mengakibatkan potensi ekologi dieksploitasi semaksimal mungkin. Dengan mengeksploitasi potensi ekologi, berakibat pola permukiman lebih mapan dan senantiasa tersedia sumber makanan yang dibutuhkan. Hal tersebut berdampak adanya ledakan penduduk.

Dengan kenyataan yang telah diuraikan di atas, tampak jelas bah-wa pola permukiman pendukung Budaya Toala mampu bertahan lama, disebabkan karena pola adaptasi yang diterapkan sudah mapan dan sta-bil. Pola adaptasi tersebut yaitu pola musiman dengan penjadualan mengakibatkan terjadinya ledakan penduduk yang selanjutnya berkem-bang dengan keinginginan untuk hidup menetap. Untuk memahami pro-ses terjadinya perubahan pola permukiman dari berpindah-pindah ke permukiman menetap perlu penelitian lebih lanjut.

\section{KEPUSTAKAAN}

Anthony, J. Whitten, 1987, Ekologi Sulawesi, Yogyakarta: Gadjah Mada Press.

Bargamini, David, 1981, Alam dan Margastwa Australasia, diterjemahkan oleh T.W. Kamil, Jakarta: Tira Pustaka.

Glover, lan C., Bernnet Bronson, 1984, Archaeological Radiocarbon Dates from Indonesia: A First List, Indonesia Circle No. 34, June 1984, hlm. 37 - 44.

Green, L. Ernestene, 1973, Population, In Search of Man, ed., Ernestene L. Green, Boston: Little, Brown and Company, hlm. $339-340$.

Heekeren, van H.R., 1972 The Stone Age of Indonesia, Second rev. ed., VKI No. LXI, The Hague - Martinus Nijhoof. 
Indah Asikin Nurani, 1992, Tinjauan tentang Pola Permukiman Pendukung Budaya Toala di Sulawesi Selatan, PIA VI, belum diterbitkan.

SPSP Sulawesi Selatan, 1986, Laporan Pengumpulan Data Peninggalan Sejarah dan Purbakala di Kabupaten Bantaeng, tidak diterbitkan.

Sumarwoto, Otto, 1987, Ekologi, Lingkungan, dan Pembangunan, Bandung: Penerbit Djambatan.

Trigger, Bruce G., 1973, The Study of Settlement in Archaeology, In Search of Man, ed., Erneste L. Green, Boston: Little, Brown and Company, hlm. 312 - 320 .

\section{LAMPIRAN}

Daftar No. 1: Distribusi Temuan Sisa-sisa Fauna Toalean

\begin{tabular}{|c|c|c|c|c|c|c|c|c|c|c|}
\hline Jenis Fauna & P.T & PRGI & PRGII & B.E & Codg & Lmp & B.Bt & Krss & Sip & PatE \\
\hline Phaianger ursinus & $\bar{V}$ & V & $\mathrm{V}$ & $\bar{v}$ & - & - & 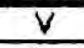 & $V$ & $\mathrm{~V}$ & $\mathrm{~V}$ \\
\hline Phalanger celebensis & - & $\bar{V}$ & $\bar{V}$ & $\bar{v}$ & - & - & $\bar{V}$ & $\bar{V}$ & $\bar{V}$ & - \\
\hline Suncus munnus & - & - & - & - & - & - & $\bar{V}$ & - & - & - \\
\hline Macaca maura & $\bar{V}$ & $\bar{V}$ & $\bar{V}$ & $\bar{V}$ & $\mathrm{~V}$ & - & V & $\mathrm{V}$ & V & $\bar{v}$ \\
\hline Homo sapiens & - & $\bar{V}$ & $\bar{V}$ & $\bar{V}$ & $\bar{V}$ & $\bar{V}$ & $\bar{V}$ & $\bar{V}$ & - & - \\
\hline Lenormys meveri & - & $V$ & $V$ & $\mathrm{~V}$ & - & - & V & - & - & - \\
\hline Rattus of xanthurus & - & $\mathrm{V}$ & $\mathrm{V}$ & V & - & - & $\mathrm{V}$ & - & - & - \\
\hline Rattus cf. rattus & $\bar{V}$ & V & - & - & - & - & V & - & - & - \\
\hline Rattus cf coelests & - & - & - & - & - & - & $\bar{v}$ & - & - & - \\
\hline Macrogalidia m. & - & - & - & - & - & - & $\bar{V}$ & - & - & - \\
\hline Sus cetebensis & $\bar{V}$ & $\bar{V}$ & $\bar{v}$ & V & $\bar{V}$ & $\bar{V}$ & $\bar{V}$ & $\bar{V}$ & $\bar{V}$ & $\bar{V}$ \\
\hline Babyrussa babyrussa & V & v & V & $V$ & V & V & V & V & - & 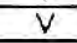 \\
\hline Anoa quertesi & $\bar{V}$ & V & $\mathrm{V}$ & $\mathrm{V}$ & V & - & V & $?$ & - & - \\
\hline Anoa depressicomis & - & $?$ & $?$ & - & - & - & - & - & - & - \\
\hline
\end{tabular}

Catatan: - : tldak ditemukan $\quad v$ : dttemukan

$\begin{array}{ll}\text { P.T. : Panisis Tabuttu } & \text { Lmp : Lampoa } \\ \text { B.Bt.: Bola Batu } & \text { Prgl : Panganreang I } \\ \text { Krss : Karassa } & \text { Prgll : Panganreang II } \\ \text { Srp.: Sarlpa } & \text { B.E : Batu Ejaya } \\ \text { PatE : PattaE } & \text { Cdg : Cadang }\end{array}$




\section{Daftar No. 2: Persebaran Temuan Unsur-unsur Budaya Toala}

\begin{tabular}{|c|c|c|c|c|c|c|c|c|c|}
\hline \multirow{3}{*}{ No } & \multirow{3}{*}{ Nama siturs } & \multirow{3}{*}{ Kabupaten } & \multicolumn{7}{|c|}{ Unsur-unsur Budara Toala } \\
\hline & & & \multirow{2}{*}{$\frac{\text { T.HII }}{\text { Sb ksr }}$} & \multicolumn{3}{|c|}{ TOALAII } & \multicolumn{3}{|c|}{ TONLAI } \\
\hline & & & & So bi & Mrikt & Mo bdr & Mo brg & L.Mdk & Tmbkr \\
\hline 01. & Leang Karassa & MAROS & $v$ & - & - & - & - & - & $v$ \\
\hline 02 & Leang Burung 2 & soa & $v$ & - & - & - & - & - & - \\
\hline 03. & Leang Saripa & sda & - & $v$ & $v$ & v & $v$ & $v$ & - \\
\hline 04 & Leang Burung & soja & - & - & - & $\mathrm{v}$ & $v$ & $v$ & $v$ \\
\hline 05 & Leang PattaE & sda & - & $\bar{v}$ & $v$ & $\checkmark$ & $v$ & $y$ & - \\
\hline 06 & Ulu Leang & sda & - & $v$ & $v$ & $v$ & $\mathrm{v}$ & $v$ & $\mathbf{v}$ \\
\hline 07. & Leang Cakondo & BONE & - & $v$ & - & $v$ & - & - & - \\
\hline 08. & Leang Uluieba & sda & - & $v$ & - & $v$ & $=$ & - & - \\
\hline 08 & Leang Bairsao & sda & - & $\bar{v}$ & - & $v$ & - & - & - \\
\hline 10 & Leang Tomatua $\mathrm{K}$ & sda & - & $v$ & - & $y$ & $\cdot$ & - & - \\
\hline 11 & Leang Panisi $T$ & sda & $v$ & - & - & - & - & - & - \\
\hline 12. & Gua Bola Batu & sda & - & $v$ & $v$ & $v$ & - & $v$ & - \\
\hline 13. & Gua Cadang & sda & - & - & - & $y$ & - & - & $v$ \\
\hline 14. & Gua Panganreang & BANTAENG & $v$ & $v$ & $v$ & v & - & $v$ & 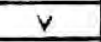 \\
\hline $\begin{array}{l}15 . \\
16 .\end{array}$ & $\begin{array}{l}\text { Gua Batu Ejaya } \\
\text { Gua Ara }\end{array}$ & $\begin{array}{c}\text { sda } \\
\text { BULUKUMBA }\end{array}$ & . & $\begin{array}{l}v \\
-\end{array}$ & 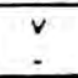 & - & v & $\begin{array}{l}v \\
v\end{array}$ & $\begin{array}{l}v \\
v\end{array}$ \\
\hline
\end{tabular}

Catatan: - : tidak ditemukan

v: ditemukan

Sb.ksr: serpih bilah kasar

Sp.bi.: serpih bilah

Mkrt. : mikrolit

Mp.bdr: mata panah berdasar bundar

Mp.brg: mata panah berdasar bergerigi

L.Mdk.: Iancipan muduk

Tmbkr : tembikar 
Daftar No. 3: Persebaran dan Jangka Waktu Hunian Situs-situs Gua Budaya Toala

\begin{tabular}{|c|c|c|c|c|c|}
\hline \multirow{2}{*}{ No. } & \multirow[t]{2}{*}{ Nama sthus } & \multirow[t]{2}{*}{ Lingkungan } & \multicolumn{3}{|c|}{ Jangka Waktu Hunian } \\
\hline & & & $T$ III & $T \|$ & $T I$ \\
\hline 01. & Leang Karassa & Pegunungan & $v$ & - & - \\
\hline 02. & Leang Burung 2 & sda & $v$ & - & - \\
\hline 03. & Leang Saripa & sda & - & $v$ & $\mathrm{v}$ \\
\hline O4. & Leang Burung 1 & Lembah & - & - & $v$ \\
\hline 05. & Leang PettaE & sda & - & $\mathrm{v}$ & $v$ \\
\hline 06. & Ulu Leang & sda & - & $v$ & $\mathbf{v}$ \\
\hline 07. & Laang Cakondo & Pegunungan & - & $v$ & - \\
\hline 08. & Leang Ululeba & sda & - & $v$ & - \\
\hline 09. & Leang Ballsao & sda & - & $v$ & - \\
\hline 10. & Leang Tomatua $\mathrm{K}$. & sda & - & $\mathrm{v}$ & - \\
\hline 11. & Leang Panisi $T$. & sda & $v$ & - & - \\
\hline 12. & Gua Bola Balu & sda & - & v & - \\
\hline 13. & Gua Cadang & sda & - & $\mathbf{v}$ & - \\
\hline 14. & Gua Panganreang & Pantal & $v$ & $v$ & $v$ \\
\hline 15. & Gua Batu Elaya & sda & - & $v$ & $v$ \\
\hline 16. & Gua Are & sda & - & - & $v$ \\
\hline
\end{tabular}

Catatan: - : tidak dihuni

$$
v \text { : dihuni }
$$

Daftar No. 4: Banyakmya Situs Dalam Daerah Sebaran dan Waktu Penghunian

\begin{tabular}{|l|c|c|c|}
\hline \multirow{2}{*}{ Daerah Sebaran } & \multicolumn{3}{|c|}{ Waktu Penghunian } \\
\cline { 2 - 4 } & Toala III & Toala II & Toala I \\
\hline & & & \\
\hline Pantai & 1 & 2 & 3 \\
\hline Lembah & 0 & 2 & 3 \\
\hline Pegunungan & 3 & 7 & 3 \\
\hline & 4 & 11 & 7 \\
\hline
\end{tabular}


Daftar No. 5: Kronologi Lapisan Budaya Toala

\begin{tabular}{|l|l|c|}
\hline Lap.Budaya & \multicolumn{1}{|c|}{ Indikator Temuan } & Pertanggalan \\
\hline TOALA I & Tembikar tradisi Sahuynh-Kalanay. & $700-400 \mathrm{SM}$ \\
\hline & Tembikar polos berasosiasi dengan & $4000 \mathrm{SM}$ \\
\hline & yang telah didomestikkan yaitu jenis & \\
\hline & Oryza sattiva & \\
\hline TOALA II & Mikrolit, serpih bilah, tulang Babi ber- & $5740 \pm 230 \mathrm{BP}$ \\
\hline & $\begin{array}{l}\text { asosiasi dg. arang dan kerang air } \\
\text { tawar }\end{array}$ & $10740 \pm 50 \mathrm{BP}$ \\
\hline TOALA III & Serpih bilah, lancipan Levallois ber- & $20150 \pm 250 \mathrm{BP}$ \\
\hline & asosiasi dg.arang dan kerang air tawar 32160 $3250 \mathrm{BP}$ \\
\hline
\end{tabular}




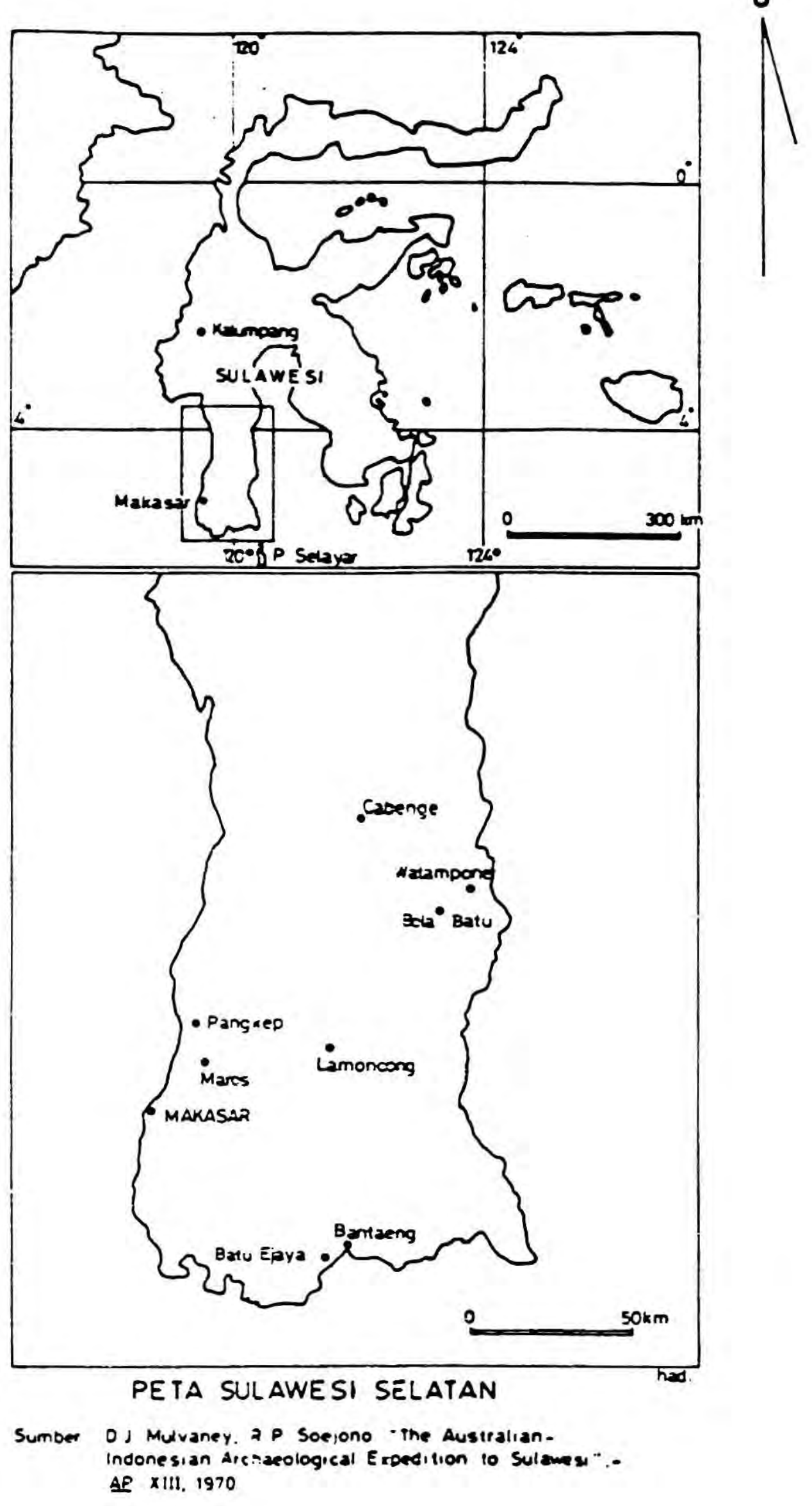




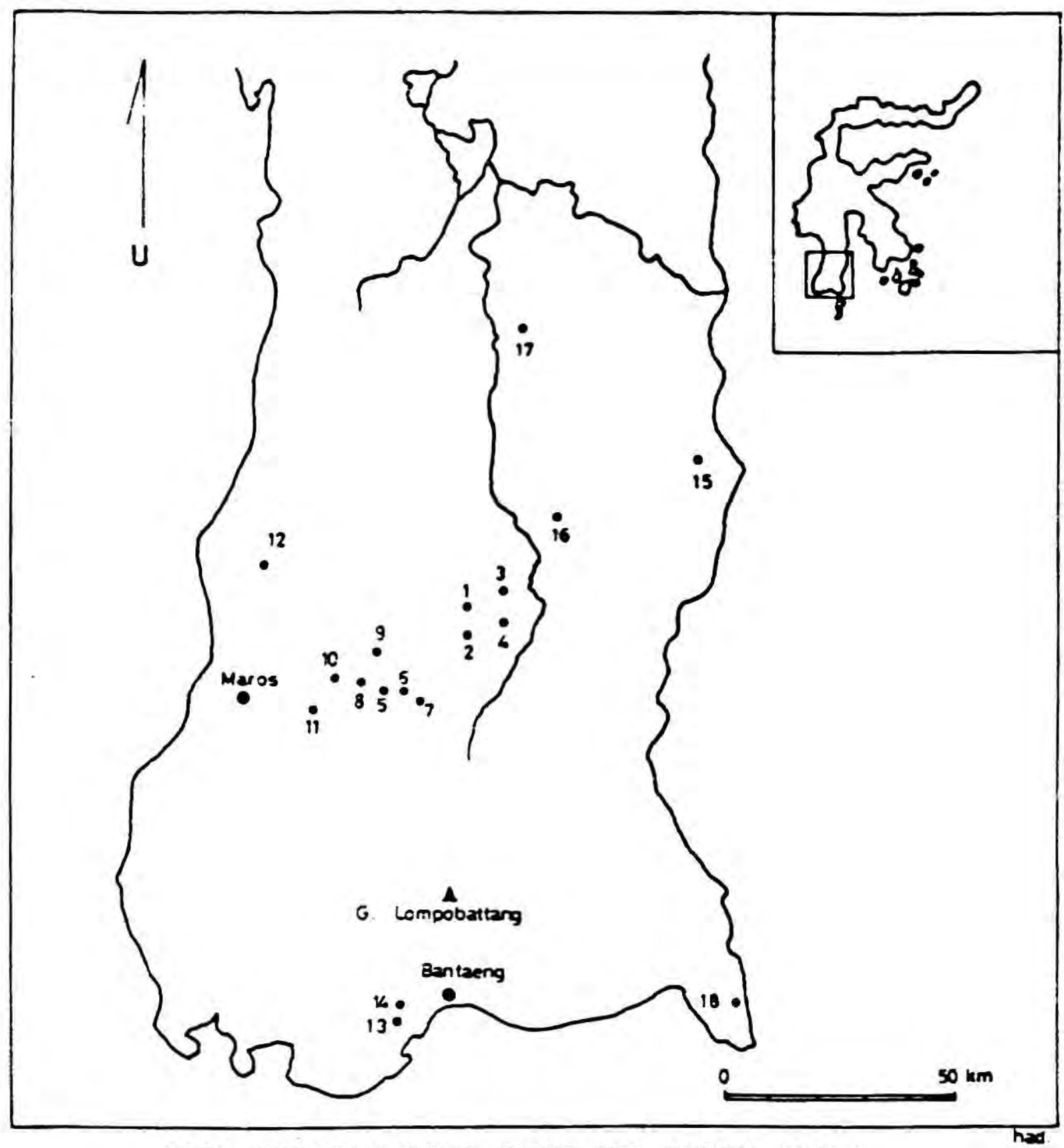

PETA SEBARAN SITUS-SITUS GUA BUDAYA TOALA

KETERANGAN

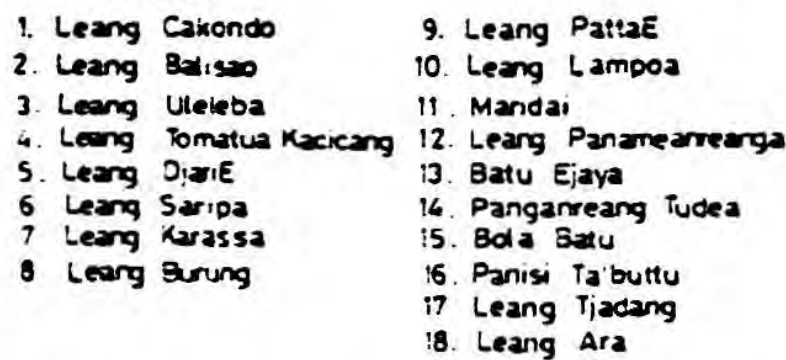

sumber HA van meexeren. "The Stone age of Indonesua". Second rev ed. VKI LKI.

( The Hage-Martinus Ninott. :572). nim :07 